F. med. Genet. (1966). 3, 258.

\title{
A Complex Pattern of Chromosome Abnormalities i the Acute Phase of Chronic Granulocytic Leukaemia
}

\author{
P. H. FITZGERALD \\ From the Cytogenetics Unit*, Christchurch Hospital, Christchurch, New Zealand
}

The Philadelphia chromosome $\left(\mathrm{Ph}^{1}\right)$ is of particular interest because of its close association with chronic granulocytic leukaemia. $\mathrm{Ph}^{1}$ is a distinct chromosome abnormality which is found in the marrow or blood cells of nearly all patients with this leukaemia, and appears to be generally specific to this or closely related disorders. Because of these features, $\mathrm{Ph}^{1}$, unlike the chromosome abnormalities found in other tumours, has a strong claim to a close association with the aetiology of chronic granulocytic leukaemia, but a causal role has not been established. During the chronic phase of this leukaemia, $\mathrm{Ph}^{1}$ is the only detectable chromosome change in the majority of cases, whereas in the acute terminal stages, $\mathbf{P h}^{1}$ is commonly associated with other chromosome abnormalities which vary considerably between patients. These secondary abnormalities resemble those found in acute leukaemia which is also characterized by a great variety of chromosome abnormalities, probably as a secondary development of the leukaemic state. Investigations of the transition from specificity to diversity of chromosome abnormality in chronic granulocytic leukaemia are of particular importance, because they might be expected to give some insight, not only into the relationship of chromosome abnormalities to tumour progression, but also into the nature of the specificity of the $\mathrm{Ph}^{1}$ chromosome itself.

The present paper reports a complex pattern of chromosome abnormalities in the bone-marrow cells of a 4I-year-old male patient, in the acute phase of the disease, who was a subject of earlier reports (Adams, Fitzgerald, and Gunz, 1961 ; Fitzgerald, Adams, and Gunz, 1963). Detailed examination of the earlier material and of new material from this man revealed abnormalities of $G$ group chromosomes additional to those reported previously,

\footnotetext{
Received May 31, 1966.

*Supported by the Canterbury and Westland Division of the Cancer Society of New Zealand.
}

and also, that the abnormal sizes of the G chromosomes had caused $\mathrm{Ph}^{1}$ to be overlooked in cells thought previously to be without it.

\section{Case History}

Details of clinical findings and therapeutic measure were presented in an earlier paper (Adams et al., 196I The salient features of the now complete case history are as follows: diagnosis of chronic granulocytic leug kaemia in the 34-year-old male patient in 1954; treatment with splenic $X$ radiation, ${ }^{32} \mathrm{P}$, and busulphar $\overrightarrow{0}$ which caused an unusually long series of remissiong lasting until March I96I when the disease entered an acute phase; treatment with 6-mercaptopurine ang prednisone, which resulted in a further remission an return to a practically normal cell composition in marrov and blood; continuation of this remission until the deat of the patient in November 196I as a result of a tumou甲 of the pancreas (Angus and Gunz, 1963). Necrops revealed an adenocarcinoma of high malignancy in the pancreas and widespread secondary growths. The bone-marrow showed tumour deposits as well as group of blasts.

\section{Chromosome Findings}

The chromosomes were examined in marrow celis prepared by a direct method detailed elsewhere (Adams et al., I96I). Revised chromosome counts in cells of the March, June, and July 196I marrow preparation from this patient, and the findings in a further marrow preparation obtained in October of the same yeac, shortly before the patient died, are shown in Table These include only those cells in which all of the small. acrocentric chromosomes could be identified clearly The $\mathbf{P h}^{1}$ chromosome was present in all these cells. The four marrow samples showed many polyploid cellis mostly tetraploid, nearly all of which were unsuitable for chromosome analysis. The percentage of polyploid mitoses in each of the four marrow preparations if shown in Table II.

The results of an analysis of the $\mathrm{G}$ chromosome group (Nos. 21, 22, and Y) in the diploid and near diploid cells are summarized in Table III. For convenience of presentation attention will be confined first to tho March marrow preparation. Four cell types, each 
TABLE I

CHROMOSOME COUNTS IN THE MARCH, JUNE, JULY, AND OCTOBER I96I, MARROW SAMPLES PREPARED BY DIRECT METHOD

\begin{tabular}{|c|c|c|c|c|c|c|c|c|c|}
\hline & \multicolumn{7}{|c|}{ Number of Chromosomes } & \multirow{2}{*}{$\begin{array}{l}\text { Total } \\
\text { Cells }\end{array}$} & \multirow{2}{*}{$\begin{array}{l}\text { No. of } \\
\text { Cells } \\
\text { with Ph }\end{array}$} \\
\hline & 4I & 42 & 43 & 44 & 45 & 46 & 47 & & \\
\hline $\begin{array}{l}\text { March } \\
\text { June } \\
\text { July } \\
\text { October }\end{array}$ & I & - & I & $\begin{array}{l}\mathbf{I} \\
\mathbf{I}\end{array}$ & $\begin{array}{l}6 \\
5 \\
1 \\
5\end{array}$ & $\begin{array}{l}42 \\
45 \\
33 \\
42\end{array}$ & I & $\begin{array}{l}51 \\
50 \\
35 \\
50\end{array}$ & $\begin{array}{l}51 \\
50 \\
35 \\
50\end{array}$ \\
\hline
\end{tabular}

Note: Polyploid cells were assessed independently, and are shown in Table II.

\section{TABLE II}

PERCENTAGE FREQUENCIES OF SIX CELL LINES I-VI IN DIPLOID AND NEAR DIPLOID CELLS, AND PERCENTAGE POLYPLOID MITOSES (ASSESSED INDEPENDENTLY) IN MARCH, JUNE, JULY, AND OCTOBER MARROW PREPARATIONS

Marrow Preparation

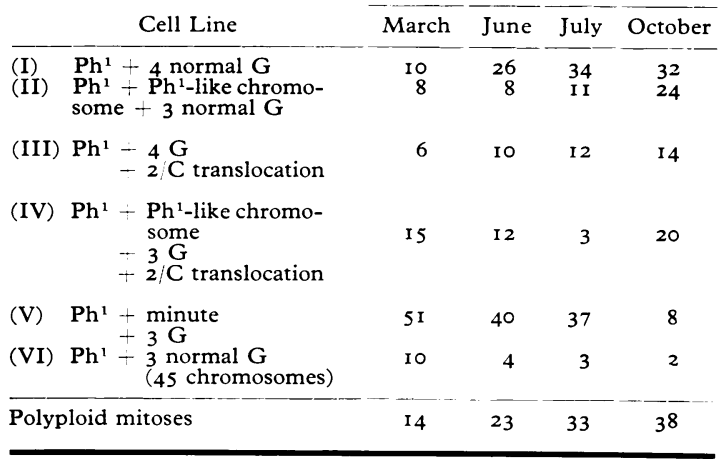

characterized by distinct abnormalities of the small acrocentric chromosomes, were recognized.

(I) $\mathrm{The}^{\mathrm{Ph}^{1}}$ chromosome, and 4 normal G chromosomes (Fig. I).

(2) The $\mathrm{Ph}^{1}$ chromosome, another abnormal G chromosome with the same general sub-metacentric appearance as $\mathrm{Ph}^{1}$ but larger, and 3 normal G chromosomes (Fig. 2, 3).

(3) $\mathrm{The} \mathrm{Ph}^{1}$ chromosome, a centric minute fragment representing one of the other small acrocentric chromosomes, and 3 normal G chromosomes (Fig. 4).

(4) The $\mathrm{Ph}^{1}$ chromosome, and only 3 other small acrocentric chromosomes (Fig. 5).

A G group chromosome was missing from these cells which accounted for 5 of the 6 cells with 45 chromosomes.

Cell types $\mathrm{I}$ and 3 , and a translocation of part of the long arm of a $\mathrm{C}$ group chromosome to the long arm of a No. 2 chromosome (Fig. 3), were described previously (Adams et al., 196I).

The $2 / \mathrm{C}$ translocation was present in some cells of types I and 2, and absent from others, but was never present in cell types 3 and 4 (Table III). The lack of association in the same cell of the translocation and the minute indicates that they originated independently of each other in different cell lines. The absence of the translocation from both cell types 3 and 4 supports the view that type 4 cells were derived from type 3 cells by loss of the minute chromosome.

The June, July, and October, marrows, all of which were prepared by the direct technique, showed the same four cell types as were present in the March preparation (Table III). Likewise, the $2 / \mathrm{C}$ translocation was present in some cells and absent from others belonging to cell types $\mathrm{I}$ and 2, and was never present in cell types 3 and 4 .

Reference to Table III will show that use of the 2/C translocation as an additional criterion allows the distinction of six cell lines in the marrow samples. The probable sequence of their formation is shown in Fig. 6. It can be assumed that the sequence started with a cell line showing a normal chromosome complement apart from the $\mathrm{Ph}^{1}$ chromosome (cell-line I). The second $\mathrm{Ph}^{1}$-like chromosome appears to have developed twice to form cell lines II and IV. This abnormal chromosome is probably due to a single deletion, and for this reason it is more likely to have occurred twice than is the more complex translocation, as would otherwise be necessary to explain the presence of cell

TABLE III

ANALYSIS OF NOS. 21, 22, AND Y CHROMOSOMES (G GROUP) AND INCIDENCE OF THE 2/C TRANSLOCATION IN CELLS FROM MARROW PREPARATIONS OF MARCH, JUNE, JULY, AND OCTOBER I $96 \mathrm{I}$

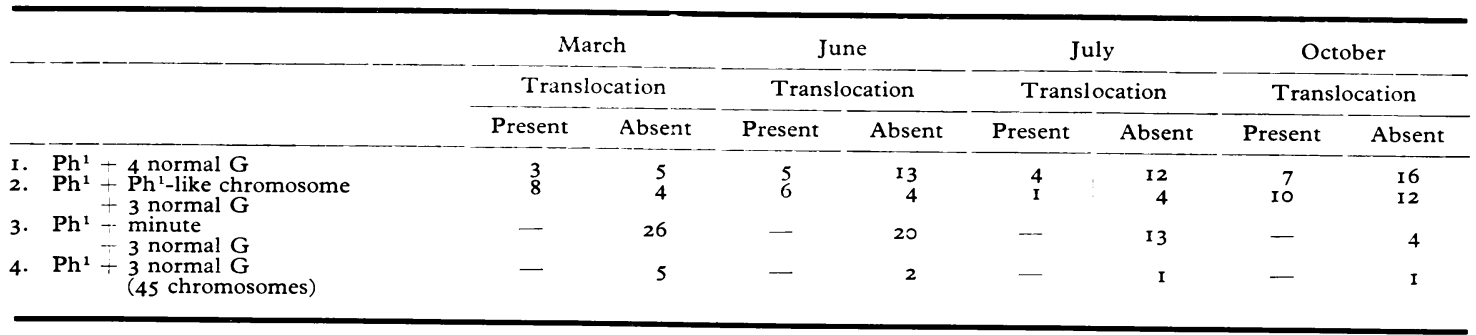

Note: The figures in the table are numbers of cells. 


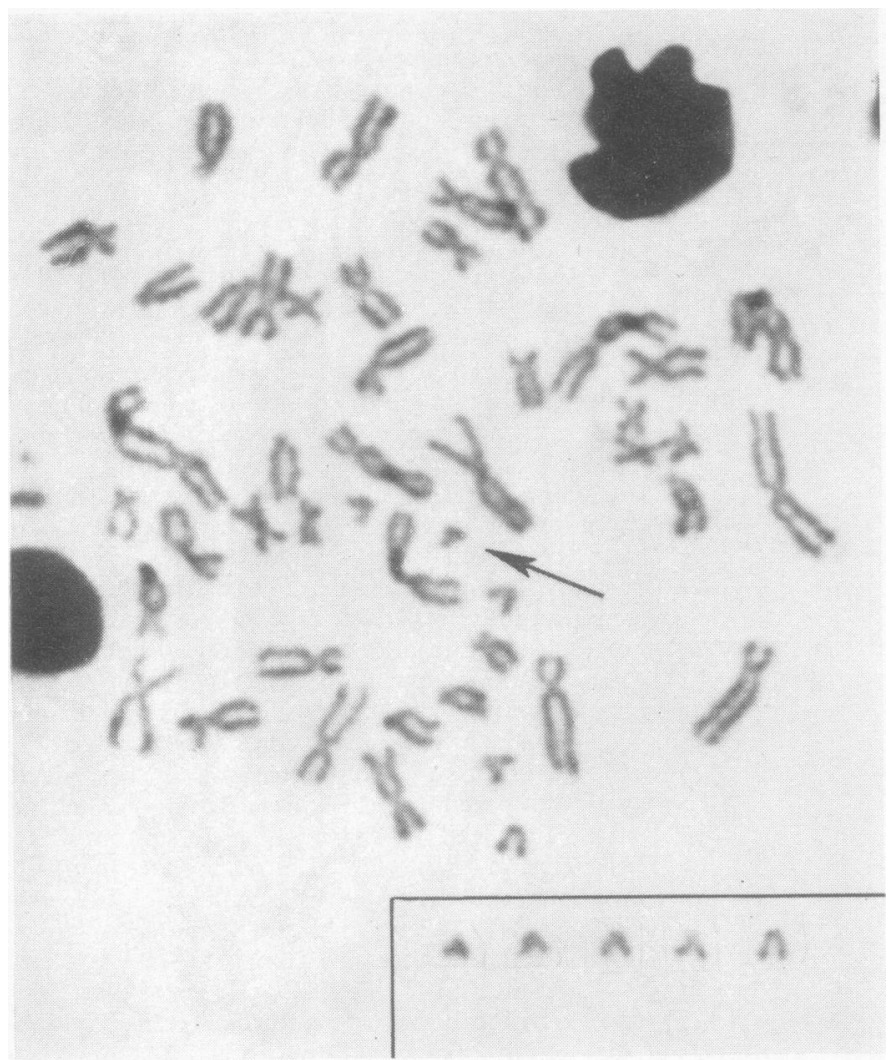

Fig. I. Bone-marrow cell with 46 chromosomes showing a $\mathrm{Ph}^{1}$ chromosome (arrow). The $G$ group chromosomes are shown separately at the lower right in the order: $\mathrm{Ph}^{1}$ 3 normal autosomes, and the $Y$ chromosome.

Fig. 2. Bone-marrow cell with 46 chromosomes showing two $\mathrm{Ph}^{1}$-like chromosomes (arrows). The G group chromosomes are shown separately at the lower right in the order: $\mathbf{P h}^{1}$, second $\mathbf{P h}^{1}$-like chromosome, and 3 normal acrocentrics. The longer chromosome in the fifth position is probably the $\mathrm{Y}$. 
FIG. 3. Bone-marrow cell with 46 chromosomes showing two $\mathbf{P h}^{1}$-like chromosomes (light arrows). The G group chromosomes are shown separately at the lower right in the order: two $\mathrm{Ph}^{1}$-like chromosomes and 3 normal acrocentrics, with the probable $\mathrm{Y}$ in the fifth position. The No. $2 / \mathrm{C}$ group translocation is indicated (heavy arrow).

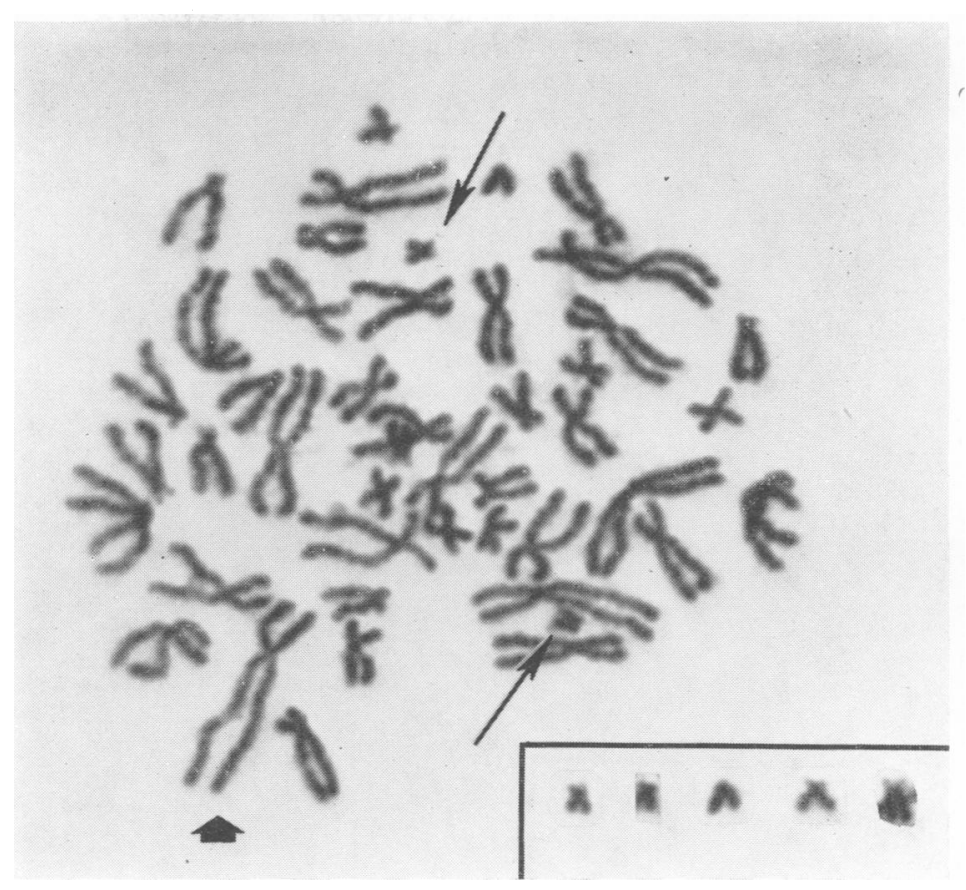

Fig. 4. Bone-marrow cell with 46 chromosomes showing $\mathrm{Ph}^{1}$ and the centric minute (arrows). The $G$ group chromosomes are shown separately at the lower right in the order: $\mathbf{P h}^{1}$, centric minute, and 3 normal acrocentrics.

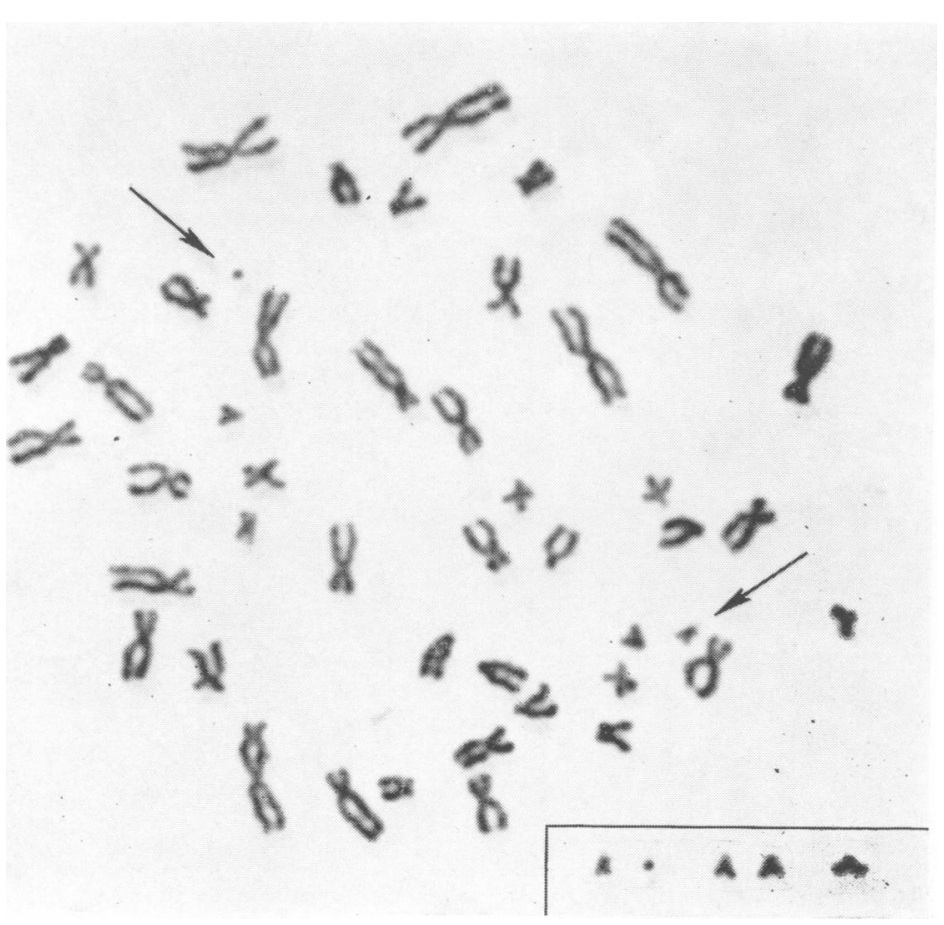




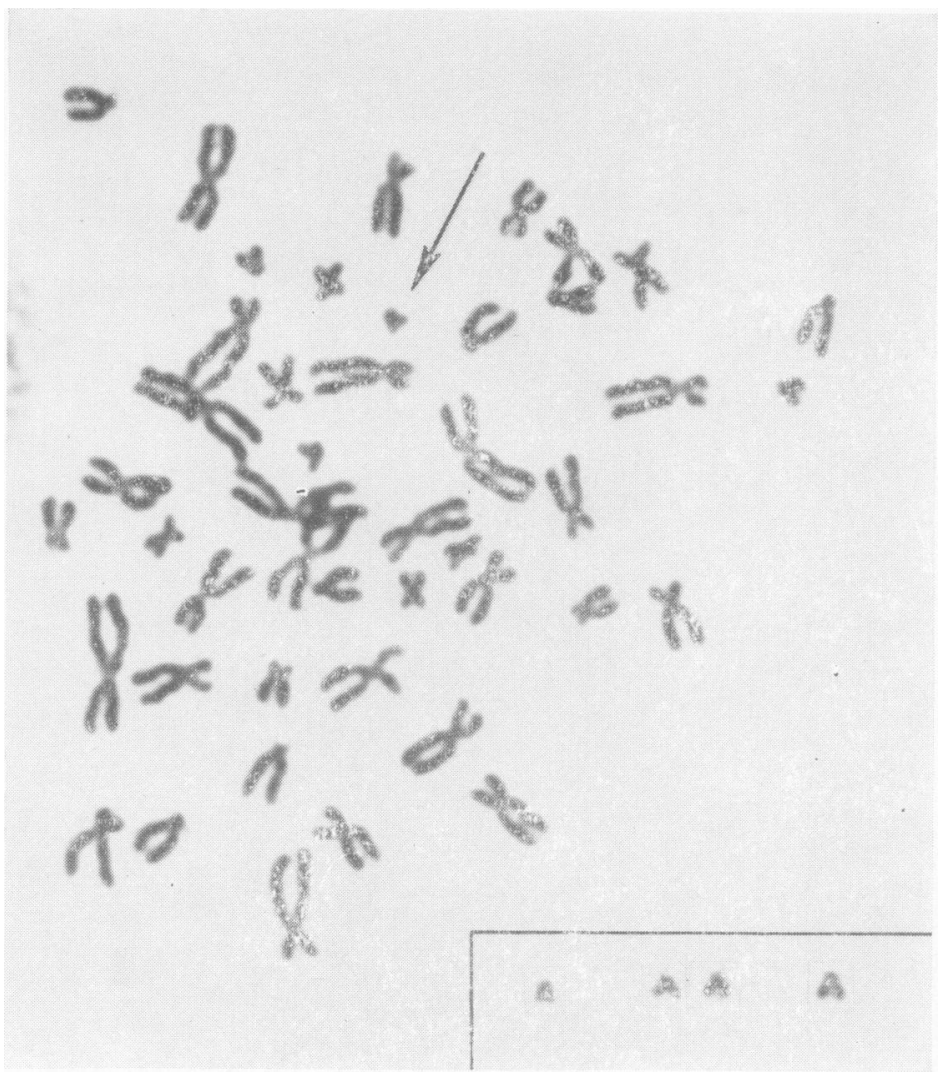

FIG. 5. Bone-marrow cell with 45 chromosomes showing $\mathrm{Ph}^{1}$ (arrow) and the absence of a small acrocentric chromosome. The four $G$ group chromosomes are shown at the lower right in the order: $\mathrm{Ph}^{1}$ and 3 normal acrocentrics.

types II, III, and IV. Cell line VI was possibly formed from cell line $\mathrm{V}$ by loss of the centric remnant, but it is also possible that VI resulted from I independently of $\mathrm{V}$ by complete loss of a small acrocentric chromosome.

The percentage frequencies of the six cell lines in the
March, June, July, and October marrow preparations are shown in Table II. The most striking feature was. the drop in frequency, particularly in the October sample, of cells showing the minute chromosome. (cell line V). A similar drop was apparent in the fre- $\mathrm{O}$

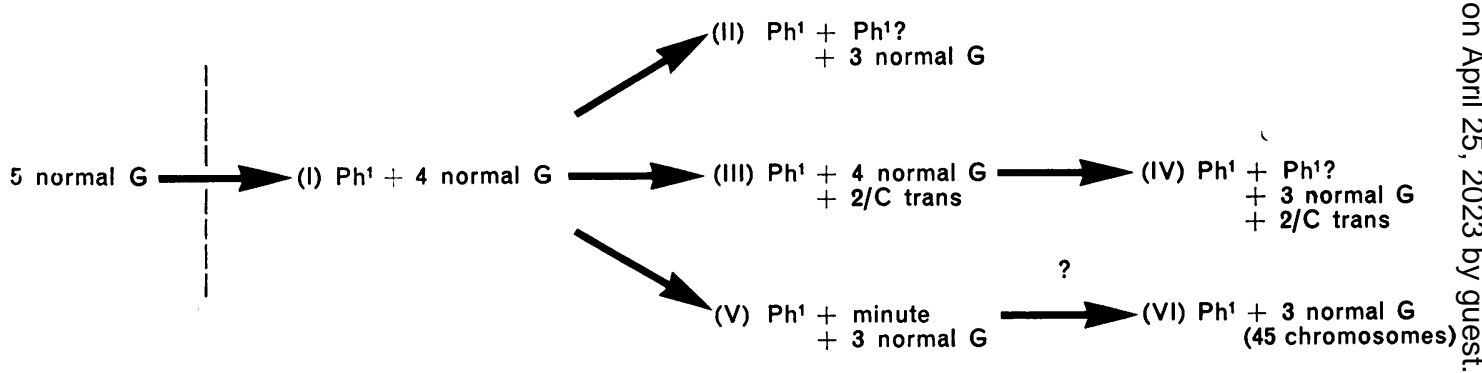

Fig. 6. Diagram showing the probable sequence of formation of the six cell lines (I-VI) present in the marrow. $G$ refers to normal small 7 acrocentric chromosomes in the $\mathrm{G}$ group (Nos. $2 \mathrm{I}, \mathbf{2 2}$, and $\mathrm{Y}$ ) $\mathrm{Ph}^{1}$ ? refers to the second $\mathrm{Ph}^{1}-\mathrm{like}$ chromosome, and $2 / C$ trans refers 0 to the translocation between a No.2 chromosome and a member of the $C$ group. 
quency of cell line VI, though fewer cells were involved. Corresponding to the decreased frequencies of cell lines $\mathrm{V}$ and VI were the increased frequencies of the other cell lines. I and III showed an increase in the June, July, and October samples, whereas II and IV (with $2 \mathrm{Ph}^{1}$-like chromosomes) increased only in the October sample. The final increase in frequency was threefold in cell lines I and II, and somewhat less in those lines (III and IV) carrying the translocation.

\section{Discussion}

The marrow cells of this patient showed a complex of abnormalities mainly affecting the G chromosomes but also the $\mathrm{A}$ and $\mathrm{C}$ groups. All cells showed the $\mathrm{Ph}^{1}$ chromosome, which is believed to be concerned closely with the origin of chronic granulocytic leukaemia, and many cells also showed additional $\mathrm{G}$ chromosome abnormalities, namely, a second $\mathrm{Ph}^{1}$-like chromosome, a minute chromosome, and complete loss of a $G$ chromosome. These appear to be secondary developments in leukaemic $\mathrm{Ph}^{1}$-positive cells, and were possibly caused by the considerable treatment the patient had received. $\mathrm{Ph}^{1}$ has been identified as an autosome, possibly No. 2I, but the identity of the other 3 abnormal $G$ chromosomes is not clear. They may have involved different chromosomes, or they may all have occurred in a particular $\mathrm{G}$ chromosome. They probably did not occur in the $\mathrm{Y}$ chromosome which appeared to be present in some of the cells with each type of $G$ abnormality, though in other cells this chromosome could not be identified clearly.

Abnormalities similar to the $G$ chromosome abnormalities in this patient have been described in other patients. Nowell and Hungerford (196I) noted a 46 chromosome cell line with $\mathrm{Ph}^{1}$ and a similar abrormally short acrocentric chromosome in a male patient who, like the present one, was in the acute blastic phase after a long history of granulocytic leukaemia, and Forteza and Báguena (I962) described the association in a male patient of $\mathrm{Ph}^{1}$ with a minute chromosome replacing another $\mathrm{G}$ chromosome. The complete absence of a G chromosome from some marrow cells of the present patient recalls the 45 chromosome cell line, including $\mathrm{Ph}^{1}$ and only 3 other small acrocentrics, which has been described in 7 male patients in the chronic phase of granulocytic leukaemia (Atkin and Taylor, 1962; Tough, Jacobs, Court Brown, Baikie, and Williamson, 1963; Speed and Lawler, 1964; Engel, Jenkins, Tipton, McGee, and Engel-de Montmollin, 1965; and one unreported case from this laboratory). The $G$ group chromosome abnormalities described in these patients are similar to those found in the present patient, but, like them, their precise identity must remain uncertain because of the obvious difficulty in identifying deleted or missing chromosomes, which is often aggravated by the abnormal appearance of the chromosomes in leukaemic cells (Atkin and Taylor, 1962). However, it may be significant that the Io patients in whom these abnormalities occurred, including the present one, were all male. Future findings of these abnormalities in male patients only would strengthen the view that the Y chromosome was involved, whereas their presence in females would indicate that they occurred in an autosome, possibly the homologue of $\mathrm{Ph}^{1}$.

It is possible that the $3 \mathrm{G}$ chromosome abnormalities in the present patient, while being the results of independent events in different cells, exhibit the progressive deletion of a particular $\mathrm{G}$ chromosome, and have similar cytogenetic effects, such as might result from the common loss of a particular locus concerned with leucopoiesis. The presence, at the one time, of clones characterized by each of the three chromosome abnormalities suggests that they were genetically similar, though not genetically identical, as is indicated by the changes in frequency of the clones in the four marrow samples. Loss of a particular locus would be achieved most readily by complete loss of a chromosome, and it is possible that the present abnormalities, if they are cytogenetically similar, are basically of the same nature as the more commonly reported absence of a $\mathrm{G}$ chromosome in cells carrying $\mathrm{Ph}^{1}$ (Atkin and Taylor, 1962; Tough et al., 1963; Speed and Lawler, 1964; Engel et al., 1965).

While the identity and relationships of these abnormal chromosomes are uncertain, complete loss, and possibly partial loss, of a small acrocentric chromosome other than $\mathrm{Ph}^{1}$ appears to be a secondary cytogenetic development in several cases of chronic granulocytic leukaemia. This repetition of the same or closely similar abnormalities in different patients recalls the $\mathrm{Ph}^{1}$ chromosome itself, and it appears that the factors determining the specific association of $\mathrm{Ph}^{1}$ with chronic granulocytic leukaemia, while most strikingly evident with $\mathrm{Ph}^{1}$, might also apply to other chromosome abnormalities. The specificity of $\mathrm{Ph}^{1}$ can have two alternative explanations. Either $\mathrm{Ph}^{1}$ is the primary somatic mutation causing the malignant transformation of myeloid cells, or it is a relatively common secondary development in leukaemic cells, and $\mathrm{Ph}^{1}$ cell lines develop in response to specific selection pressures. Likewise, the other abnormalities of the small acrocentric chromosomes, whether they are induced by therapy or occur spontaneously, may te mutations which lead to a particular develop- 
ment of leukaemia, or, on the other hand, selection pressures in the different cases of leukaemia may have been specific for cells carrying these abnormalities. It is quite possible that an existing degree of neoplasia is one of the main selection factors determining which cytogenetic abnormalities confer a reproductive advantage and lead to cell line formation, rather than the reverse, i.e. that the cytogenetic abnormalities determine the degree of neoplasia. With this in mind, the tendency for the present $G$ group abnormalities to be associated with a relatively benign course and long history of leukaemia might be taken to suggest the presence in these patients of common selection factors which have favoured the establishment of cell lines characterized by these particular chromosome abnormalities.

Necropsy of the patient showed tumour deposits as well as groups of blasts in the bone-marrow, but there can be little doubt that the marrow cells showing the chromosome abnormalities were leukaemic cells because of the presence of the $\mathrm{Ph}^{1}$ chromosome in them. This abnormality has not been found in skin cells from patients with chronic granulocytic leukaemia (Tough, Court Brown, Baikie, Buckton, Harnden, and Jacobs, 1962), and presumably does not occur in somatic cells other than blood cells. It is possible that some of the polyploid mitoses, especially those with small grossly abnormal chromosomes in the July and October marrow samples, were cells from secondary deposits of the pancreatic tumour and that these explain the rise in frequency of polyploid cells.

\section{Summary}

Six distinct cell lines, each with the $\mathrm{Ph}^{1}$ chromosome, are described with changes in their frequency in four successive bone-marrow samples from a 4I-year-old man in the acute blastic phase of chronic granulocytic leukaemia. Four of the cell lines showed abnormalities of a G group chromosome other than $\mathrm{Ph}^{1}$ : two showed the development of a second $\mathrm{Ph}^{1}$-like chromosome, one showed deletion of the major part of a G chromosome, and the fourth showed complete loss of one of these. chromosomes. It was not clear whether these abnormalities were present in different $\mathrm{G}$ chromog somes, or whether they affected the same chromos some. The reported presence in other cases off chronic granulocytic leukaemia of chromosom $\$$ abnormalities, closely similar to the above, indicates that loss, and possibly partial deletion, of a G group chromosome, apart from $\mathrm{Ph}^{1}$, is a secondary cyto genetic change of relatively common occurrence. Thus chronic granulocytic leukaemia is of particula interest not only for its association with the specifio abnormality of $\mathrm{Ph}^{1}$, but also for its frequent associa tion with other particular chromosome abnormal ${ }_{\mp}^{\omega}$ ities.

I am grateful to Miss Angela Adams for her assistance with the examination of this material.

\section{REFERENCES}

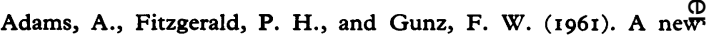
chromosome abnormality in chronic granulocytic leukaemizo Brit. med. F., 2, I 474 .

Angus, H. B., and Gunz, F. W. (1963). Chronic granulocytị leukemia and cancer. Blood, 22, 88.

Atkin, N. B., and Taylor, M. C. (1962). A case of chronic myeloiø leukaemia with a 45 -chromosome cell-line in the blood. Cytof genetics, $\mathbf{1}, 97$.

Engel, E., Jenkins, D. E., Jr., Tipton, R. E., McGee, B. J., an Engel-de Montmollin, M. (1965). $\mathrm{Ph}^{1}$-positive chronic myelö genous leukemia, with absence of another $G$ chromosome, in $\mathbb{D}$ male. New Engl. F. Med., 273, 738 .

Fitzgerald, P. H., Adams, A., and Gunz, F. W. (1963). Chronin granulocytic leukemia and the Philadelphia chromosome. Blood 21, 183 .

Forteza, G., and Báguena, R. (1962). Anomalias cromosomicas eহৃ. la leucemia mieloide cronica. Rev. Inform. medicoter., 38, 426 .

Nowell, P. C., and Hungerford, D. A. (196I). Chromosome studie'sin human leukemia. II. Chronic granulocytic leukemia. $\mathcal{f}$. naț Cancer Inst., 27, ror3.

Speed, D. E., and Lawler, S. D. (1964). Chronic granulocytic leto kaemia. The chromosomes and the disease. Lancet, $1,403$.

Tough, I. M., Court Brown, W. M., Baikie, A. G., Buckton, K. E.. Harnden, D. G., and Jacobs, P. A. (1962). Chronic myeloi\& leukaemia: cytogenetic studies before and after splenic irradiation?
ibid., 2, I 5 .

- Jacobs, P. A., Court Brown, W. M., Baikie, A. G., an Williamson, E. R. D. (1963). Cytogenetic studies on bone marrow in chronic myeloid leukaemia. ibid., 1,844 . 